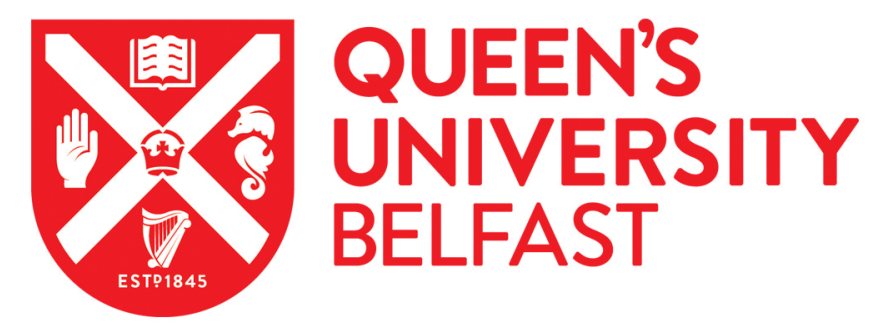

\title{
Genetic homogeneity in the deep-sea grenadier Macrourus berglax across the North Atlantic Ocean
}

Coscia, I., Castilho, R., Massa-Gallucci, A., Sacchi, C., Cunha, R. L., Stefanni, S., Helyar, S., Knutsen, H., \&

Mariani, S. (2018). Genetic homogeneity in the deep-sea grenadier Macrourus berglax across the North Atlantic Ocean. Deep-Sea Research Part I: Oceanographic Research Papers. https://doi.org/10.1016/j.dsr.2017.12.001

Published in:

Deep-Sea Research Part I: Oceanographic Research Papers

Document Version:

Peer reviewed version

Queen's University Belfast - Research Portal:

Link to publication record in Queen's University Belfast Research Portal

\section{Publisher rights}

Copyright 2017 Elsevier.

This manuscript is distributed under a Creative Commons Attribution-NonCommercial-NoDerivs License

(https://creativecommons.org/licenses/by-nc-nd/4.0/), which permits distribution and reproduction for non-commercial purposes, provided the author and source are cited.

\section{General rights}

Copyright for the publications made accessible via the Queen's University Belfast Research Portal is retained by the author(s) and / or other copyright owners and it is a condition of accessing these publications that users recognise and abide by the legal requirements associated with these rights.

Take down policy

The Research Portal is Queen's institutional repository that provides access to Queen's research output. Every effort has been made to ensure that content in the Research Portal does not infringe any person's rights, or applicable UK laws. If you discover content in the Research Portal that you believe breaches copyright or violates any law, please contact openaccess@qub.ac.uk. 
1 Genetic homogeneity in the deep-sea grenadier Macrourus berglax across the North $2 \quad$ Atlantic Ocean

Authors

4 Ilaria Coscia ${ }^{1,3^{*}}$, Rita Castilho ${ }^{2}$, Alexia Massa-Gallucci ${ }^{3}$, Carlotta Sacchi $^{3}$, Regina L.

5 Cunha $^{2}$, Sergio Stefanni ${ }^{4}$, Sarah J Helyar ${ }^{3,5}$, Halvor Knutsen ${ }^{6,7}$, Stefano Mariani ${ }^{1,3}$

6

71 School of Environment and Life Sciences, University of Salford, Salford, Greater $8 \quad$ Manchester, M5 4WT, $U K$

$9 \quad{ }^{2}$ Center of Marine Sciences (CCMAR), University of Algarve, Faro, Portugal

$10{ }^{3}$ School of Biology and Environmental Science, University College Dublin, Belfield, Dublin, 11 Ireland

$12 \quad{ }^{4}$ Stazione Zoologica A Dohrn, Villa comunale, Napoli, Italy

135 Institute of Global Food Security, Queen's University Belfast, Belfast, Northern Ireland, $14 \quad B T 97 B L, U K$

$15{ }^{6}$ Centre of Coastal Research, University of Agder. Postboks 422, N-4604 Kristiansand, 16 Norway

$17 \quad{ }^{7}$ Institute of Marine Research, PO Box 1870, N5817 Bergen, Norway 18

$19 \quad{ }^{*}$ Corresponding author: Ilaria Coscia (I.Coscia@salford.ac.uk), +44 (0)161 2957097

$20 \quad$ Keywords

21 Microsatellites, mitochondrial DNA, marine, population structure, fisheries 
23 Paucity of data on population structure and connectivity in deep sea species remains a major

24 obstacle to their sustainable management and conservation in the face of ever increasing

25 fisheries pressure and other forms of impacts on deep sea ecosystems. The roughhead

26 grenadier Macrourus berglax presents all the classical characteristics of a deep sea species,

27 such as slow growth and low fecundity, which make them particularly vulnerable to

28 anthropogenic impact, due to their low resilience to change. In this study, the population

29 structure of the roughhead grenadier is investigated throughout its geographic distribution

30 using two sets of molecular markers: a partial sequence of the Control Region of

31 mitochondrial DNA and species-specific microsatellites. No evidence of significant

32 structure was found throughout the North Atlantic, with both sets of molecular markers

33 yielding the same results of overall homogeneity. We posit two non-mutually exclusive

34 scenarios that can explain such outcome: i) substantial high gene flow among locations,

35 possibly maintained by larval stages, ii) very large effective size of post-glacially expanded

36 populations. The results can inform management strategies in this by-caught species, and

37 contribute to the broader issue of biological connectivity in the deep ocean. 
Over the last few decades, it has become routine to use genetic techniques to investigate population structure in marine fishes (Carvalho et al., 2016). The results have

$47 \quad$ led to the widespread rejection of the commonly held view that marine species are mostly panmictic, due to the lack of visible barriers to larval and adult movements (Hauser and Carvalho, 2008). The action of ocean circulation can in fact be two-fold: superficial or deepwater currents can increase gene flow by aiding individual dispersal, especially at the larval stages, but they can also act as a barrier to it, hence favouring divergence between groups. The vast majority of published studies on marine fish have dealt with coastal pelagic species, given their commercial value and/or the convenient sampling. Yet, the fishing pressure on deep-sea stocks has been steadily increasing since the 1970s (Roberts, 2002), and the depth at which fisheries operate has also been increasing at an average pace of 65.2 m per decade (Morato et al., 2006; Watson and Morato, 2013). Despite being increasingly exploited, deep-sea fish species still suffer from a paucity of data, compared to their coastal and shallow counterparts, which can have deleterious effects on their management (see Clarke et al, 2015 for a quantitative discussion). The assessment of the level and range of spatial structure of exploited species is pivotal for the sustainable harvest and management

62 (Reiss et al., 2009, Lowe and Allendorf, 2010). Given the typical life history traits of deepsea species (discrete spawning aggregations, slow growth, late maturity), any fishing

64 pressure might have serious consequences for the persistence of stocks (Baker et al., 2009).

65 Thus, it is important to gather data in order to better understand the population structure and 66 dynamics of these fish stocks, whether they are directly exploited or caught as by-catch. The most recent studies on the dynamics of deep sea fish species have reported lack or very low 

in White et al., 2009) across their vast geographic ranges, and capable of transoceanic ontogenetic migrations (Aphanopus carbo in Longmore et al., 2014). Depth has been found to represent a barrier to gene flow and promote low but significant population structuring (Haplostethus atlanticus in Carlsson et al., 2011; Etmopterus spinax in Gubili et al., 2016; Coryphaenoides rupestris and Brosme brosme in Knutsen et al., 2012, 2009; Sebastes mentella in Shum et al., 2014, Centroscymnus coelolepis in Catarino et al., 2015). Although the extent of pelagic habits typically influences the expected levels of genetic heterogeneity, even at global scales (see Gaither et al, 2016), the deeper layers of the oceans remain less understood, and no robust life-history predictors of spatial structure currently exist.

The roughhead grenadier Macrourus berglax Lacepède 1801, family Macrouridae, is a benthopelagic species occurring across the northern Atlantic Ocean, between the Georges Bank to the west, all the way to the Barents Sea as the easternmost edge. It dwells between a depth of 100 and $1000 \mathrm{~m}$, although it is especially common at depths of 300-500 m (Cohen, 1990). Data about its biology, population structure and dynamics are scarce, even though it is an important part of the by-catch in the red fish and the Greenland halibut fisheries (Garabana et al. 2016; Gonzales Costas and Murua, 2005; Gonzales costas 2010). Life history traits of this species are similar to those of other deep sea fishes: it lives long (up to Murua, 2003, Drazen et al. 2012). Spawning has been documented across the species' geographic distribution in late Winter/early Spring (Magnússon and Magnússon, 1995; Savvatimsky, 1989), although geographical differences in time of spawning might exist (Lorance et al., 2008; Garabana et al. 2016). Very little is known about the dispersal ability at different life stages of $M$. berglax: spawning migration has been hypothesised (Garabana 
et al. 2016), but not demonstrated. The other four species of the genus Macrourus (M. carinatus, M. whitsoni, M. caml and M. holotrachys), are all present exclusively in the southern hemisphere and have well-documented extended adult migration (Laptikhovsky 2011, Munster et al. 2016), while more distantly related macrourids, such as the roundnose grenadier Coryphaenoides rupestris, have been found to have a very long pelagic phase, which can last for almost a year (Lorance et al., 2008).

The population structure of $M$. berglax across its geographic range is also poorly investigated. The only published genetic study finds low differentiation, but advocates the existence of at least three units or stocks: East Greenland, West Greenland and Norwegian Sea (Katsarou and Naevdal 2001). This investigation used allozyme markers, which, due to their nature of being expressed by coding regions may poorly reflect patterns of neutral gene flow (O’Sullivan et al., 2003).

Concerns regarding the lack of data and the status of the stock of the roughhead grenadiers in the North Atlantic were recently raised by NAFO (Northwest Atlantic Fisheries Organization) and ICES (International Council for the Exploration of the Sea), given the decrease in landings of grenadiers in the North Atlantic (Gonzales Costas 2010, ICES 2015). In the NAFO Regulated Area (western Atlantic), this species is mainly caught in subareas $3 \mathrm{LMN}$, just around Flemish Cap, where it is becoming a commercially important fish despite the fishery being unregulated (Gonzales Costas and Murua, 2005). In the eastern Atlantic (ICES Area), it is by-caught with the roundnose grenadier Coryphenoides rupestris, and its stock status is unknown and unmanaged (ICES 2015).

In this study, our aim was to fill some of these knowledge gaps by investigating the population structure of the roughhead grenadier across its geographic range and over multiple years, using species-specific microsatellite markers (Helyar et al., 2010) and the mitochondrial DNA control region (CR). In particular, we tested whether spatial genetic 
heterogeneity exists in M. berglax, and whether the three stocks suggested by Katsarou and Naevdal (2001) are upheld by our data. The findings significantly enhance our understanding of past and present population structure and diversification in M. berglax, and lay the foundation for improved conservation and management of the species.

\section{Materials and Methods}

\section{Sampling}

A total of 638 individuals were sampled at eight locations across the entire species' geographic distribution, between 2000 and 2007 (Table 1), by research and commercial vessels. The sampling localities are northern Norway (Bear Island), Svalbard, East and South Greenland, Baffin Bay, Flemish Cap, Georges Bank and Hatton Bank (Fig. 1). Tissue samples were collected and stored in absolute ethanol. Fork length was measured for each individual at all except one location (Georges Bank). Finally, for all populations excluding Georges Bank, anal fin length data was collected, and for Flemish Cap and South Greenland individuals were sexed.

\section{Genetic analysis}

DNA was extracted from muscle tissue using a standard salting-out protocol (Miller et al., 1988). A 1100 bp long fragment of the mtDNA Control Region (CR) was PCR amplified from 124 individuals (Table 1) using primers L-Prol (Ostellari et al., 1996) and 12Sar-H (Palumbi et al., 1991). All PCRs were carried out in a final volume of $25 \mu$, containing $1 X$ PCR buffer (Buffer BD Advantage 2 PCR with $\mathrm{MgCl}_{2}$ ), $0.2 \mathrm{mM}$ of each dNTP, $0.2 \mu \mathrm{M}$ of each primer, $1 \mu \mathrm{l}$ of template DNA, and Taq DNA polymerase (1 unit, Taq BD Advantage ${ }^{T M}$ 2 Polymerase Mix; CLONTECH-Takara). The following PCR profile was used for the amplification: one cycle of $1 \mathrm{~min}$ at $95{ }^{\circ} \mathrm{C}, 35$ cycles of $30 \mathrm{~s}$ at $95{ }^{\circ} \mathrm{C}, 30 \mathrm{~s}$ at $52{ }^{\circ} \mathrm{C}$, and 70 
s at $68{ }^{\circ} \mathrm{C}$, and finally, one cycle of $5 \mathrm{~min}$ at $68{ }^{\circ} \mathrm{C}$. PCR products were purified with an

144 ethanol/sodium acetate precipitation, and directly sequenced using the corresponding PCR

145 primers in an automated DNA sequencer (ABI PRISM 3700) using the BigDye Deoxy

146 Terminator cycle-sequencing kit (Applied Biosystems) following manufacturer's

147 instructions. Seven microsatellites (Helyar et al., 2010) were amplified for 559 individuals,

148 starting at $95^{\circ} \mathrm{C}$ for $15 \mathrm{~min}$, followed by 35 cycles of $45 \mathrm{sec}$ at $94^{\circ} \mathrm{C}, 45 \mathrm{sec}$ at a set annealing

149 temperature, $45 \mathrm{sec}$ at $72^{\circ} \mathrm{C}$, and a final extension step of $45 \mathrm{~min}$ at $72^{\circ} \mathrm{C}$. Markers were

150 multiplexed in $10 \mu \mathrm{l}$ final volume using the QIAGEN Multiplex Kit as follows: 1) Mbe06,

151 Mbe02, Mbe03, Mbe04 at an annealing temperature of $\left.57{ }^{\circ} \mathrm{C} ; 2\right) \mathrm{Mbe} 01$, Mbe08, Mbe10 at

$15260^{\circ} \mathrm{C}$. Both reactions were then run on an $\mathrm{ABI} 3130 \mathrm{xl}$ genetic analyser for screening. Peaks

153 were scored using Genemapper 4.0 (Applied Biosystems).

$154 \quad$ Statistical analysis

155 Haplotype $(h)$ and nucleotide $(\pi)$ diversities and $\Phi_{\mathrm{ST}}$ were calculated using Arlequin 3.5

156 (Excoffier and Lischer, 2010). Significance levels of all multiple statistical tests were

157 corrected using the false discovery rate (FDR) approach (Benjamini and Hochberg, 1995)

158 implemented in the QVALUE package (Dabney et al., 2010) in R (R Core Team, 2016).

159 Mitochondrial allelic richness $\left(A_{\mathrm{R}}\right)$ was estimated using the rarefaction method (E1 160 Mousadik and Petit, 1996) as implemented in Contrib 1.02 (Petit and Pons, 1998). A median161 joining network (Bandelt et al., 1999) was calculated in PopART (http://popart.otago.ac.nz).

162 Mismatch analysis (Rogers and Harpending, 1992) was used to explore the demographic 163 history of the species, estimating both the raggedness index (rg, Harpending 1994) and the 164 sum of squared deviations (SSD, Schneider \& Excoffier 1999) using Arlequin 3.5 165 (Excoffier and Lischer, 2010). Demographic mismatch analysis is based on the null 166 hypothesis of expansion; thus, non-significant values mean non-rejection of population 
expansion. Initial and final $\theta$ estimates (before and after population growth or decline) and $\tau$ values were calculated with ARLEQUIN 3.5 (Excoffier and Lischer, 2010). Time of inferred population expansion was determined by $T_{\exp }=\tau /(2 \mu n)$, where $\mu$ is the substitution rate per base and per generation, and $n$ the number of bases of the CR fragment (Rogers \& Harpending 1992), assuming a generation time of 15 years (Fossen et al., 2003). Historical population size changes were further investigated by calculating Tajima's $D$ and Fu's $F s$ (Fu, 1997; Tajima, 1989a, 1989b) in ARLEQUIN 3.5. using jModelTest 0.1.1 (Guindon and Gascuel, 2003; Posada, 2008) via the Akaike Information Criterion (AIC). Eight independent runs (each $10^{6}$ generations and $10 \%$ burnin) were used to reach effective sample size value (ESS) of at least 200 as per the user's 180 manual.

181 For microsatellites, the frequency of null alleles was estimated using FreeNA (Chapuis and 182 Estoup, 2007). Marker neutrality was tested in LOSITAN (Antao et al., 2008) using the 183 approach described in Beaumont and Nichols (1996). GenAlEx v6 (Peakall and Smouse, $1842006)$ was employed to estimate expected $\left(H_{\mathrm{E}}\right)$ and observed $\left(H_{\mathrm{O}}\right)$ heterozygosity indices. 185 Linkage disequilibrium, allelic richness $\left(A_{\mathrm{R}}\right), F_{\mathrm{IS}}$ and $F_{\mathrm{ST}}$ were calculated in Fstat 2.9.3 186 (Goudet, 1995). Contemporary effective population size $\left(N_{\mathrm{e}}\right)$ was estimated using the 187 Linkage Disequilibrium method implemented in LDNe (Waples and Do, 2008), using 0.02 188 as minimum allowable allele frequency $\left(\mathrm{P}_{\text {crit }}\right) . N_{\mathrm{e}}$ was calculated both by location and 189 'overall', by pooling all the samples together based on the results. Population structure was 190 investigated using two approaches with different assumptions. STRUCTURE 2.3 (Falush et 191 al., 2007, 2003; Pritchard et al., 2000) was used to estimate population subdivision, allowing 

for admixture and with both correlated and independent allele frequencies using 200,000 permutations following a burn-in of 50,000, with three independent runs for each value of

$194 k$. A second approach for estimating population structure, discriminant analysis of principal 195 components (DAPC), was implemented in the R package ADEGENET (Jombart, 2008; 196 Jombart et al., 2010). The optimal number of $k$ clusters is chosen based on the associated 197 (lowest) Bayesian Information Criterion (BIC) calculated after $10^{7}$ iterations. The difference 198 in these assignment tests lies in their assumptions: while STRUCTURE 2.3 groups 199 individuals in a number $k$ of clusters by minimising Hardy-Weinberg (HWE) and linkage 200 disequilibria, DAPC groups individuals maximising the separation amongst such groups, 201 with no prior assumptions. COLONY (Jones and Wang, 2010) was used to estimate sibship 202 between sampled individuals, using Full Likelihood approach and remaining default 203 parameters. A threshold value of 0.8 was used, meaning that only pairs of individuals with 204 at least $80 \%$ probability of being fullsibs/halfsibs were considered (Bergner et al., 2014). 205 Although COLONY has proven to provide accurate results even with a low number of 206 markers (Harrison et al. 2013), given the low diversity of the present dataset the probability 207 of Type I errors cannot be disregarded (Taylor 2015). Thus, we performed the sibship 208 analysis with another package, ML-Relate (Kalinowski et al. 2006). Only the pairs identified 209 as sibs by both analyses were considered as such.

\section{Results}

212 Fork length. Baffin Bay individuals were significantly smaller than individuals from all the 213 other populations (Fig. 5 and Fig. 3 Supplementary Material), while northern Norway 214 comprised the largest individuals. The length frequency distributions show that the only 215 population with a bi-modal trend is Svalbard. 
Mitochondrial Control Region. A total of 29 haplotypes were identified in the 114 individuals sequenced across eight locations (GenBank accession Numbers: MG702365MG702488). All the diversity indices calculated for the mitochondrial DNA were found to

219 be lowest for Svalbard, with $h=0.19$ and $\pi \mathrm{o}=0.0002$. Haplotype diversity, nucleotide diversity and the average number of nucleotide differences were highest for Flemish Cap, being respectively $0.82,0.0018$ and 1.45 . Allelic richness ranged from 1 (Svalbard) to 5.6 (Baffin Bay) (Table 1). The median-joining network showed haplotypes were grouped in a

Microsatellites. No evidence of null alleles and linkage disequilibrium was identified across 

similar across locations, ranging between 0.619 (Hatton Bank) and 0.674 (Flemish Cap), while the lowest $H_{\mathrm{O}}$ was recorded in Flemish Cap and Svalbard (0.53) and the highest in Greenland (0.673 for South Greenland and 0.668 for Eastern Greenland). Heterozygote deficiency $\left(H_{\mathrm{O}}<H_{\mathrm{E}}\right)$ was detected in Svalbard and Flemish Cap, which indeed are the only samples showing a positive and significant $F_{\text {IS }}$ (Table 1). Pairwise $F_{\mathrm{ST}}$ values showed that

247 Norway was the most divergent population, with values that, despite being low, remained significant after Bonferroni's correction. Other statistically significant pairwise comparisons

249 involved Svalbard against Baffin Bay and Georges Bank, and Georges Bank against South 250 Greenland (Table 2). Nevertheless, both assignment tests (STRUCTURE and ADEGENET) employed failed to detect significant spatial population structure within the study area (Fig. 3 and Fig. 1 Supplementary Material). DAPC results did not show any significant geographical pattern, even when repeated with populations grouped by year of capture (Fig. 3) or age class (data not shown). Effective population size was calculated both by location and by pooling all the samples together, and every estimate had an infinite estimate of the parameter. COLONY and ML-RELATE found 15 pairs of half-sibs and no full-sibs (Table 1 Supplementary Material and see Fig. 1 for a graphical representation) with no particular 258 pattern.

\section{Discussion}

The roughhead grenadier Macrourus berglax is an important part of the by-catch of halibut and redfish fisheries, but is to some extent also targeted by smaller fisheries. Thus, in the absence of a management plan, compounded with lack of information on the population biology, any form of management strategy is hindered. The species is managed throughout its range by two agencies, NAFO in the Northwest Atlantic and ICES in the Northeast Atlantic. NAFO does not have specific regulations for the roughhead grenadier, and ICES 
concludes that "no direct fishery should be allowed and that by-catch should be accounted

267 for against the TAC” (ICES, 2015).

268 In the only previously published work on population genetic structure of $M$. berglax, 269 Katsarou and Naevdal (2001) found low overall genetic diversity, but still called for each 270 subarea (West Greenland, East Greenland and Norway) to be managed as an independent 271 unit, as at least two out of the ten markers they used show heterogeneity. The authors called 272 for further investigations using more/different markers and a more intensive sampling design. This has been implemented in the current study, where mitochondrial DNA and 274 nuclear hypervariable markers are simultaneously used, but still fail to support any evidence 275 of population structure. This aligns M. berglax with several other demersal and pelagic deep 276 sea fish species, such as the roundnose grenadier (White et al. 2010), the longnose velvet 277 dogfish (Cunha et al., 2012), the Mediterranean grenadier (Catarino et al., 2013) and the black scabbard fish (Longmore et al. 2014), which were found to be largely genetically 279 homogeneous at oceanic level.

280 We used two different markers in order to investigate demographic processes at different 281 time scales: while the fast-evolving microsatellites are more suitable to untangle 282 contemporary structure (Hewitt, 2004), the mtDNA control region is usually employed to 283 unravel more ancient events on the evolutionary time scale, as well as track maternal 284 effects (being maternally inherited) (Avise, 2000). Hence, comparing and contrasting the 285 results from the two datasets can provide important insights into the processes that have 286 brought the species to be distributed as it is observed today.

287 From a management perspective, the lack of genetic differentiation at neutral markers 288 (microsatellites, markers not linked to parts of the genome under directional selection) 289 does not necessarily coincide with the existence of one single unit/stock. In marine 290 populations, low $F_{\mathrm{ST}}$ from neutral markers often reflect very large effective population size 

in recently expanded populations, rather than the existence of substantial gene flow rates

292 (Cano et al., 2008), and this could be the case for the roughhead grenadier, whose estimates of effective size are very large. In this scenario, even in the presence of low gene

294 flow, such large effective population size might be enough to counteract the divergence caused by genetic drift, especially over a few generations, such as in the case of the slowgrowing M. berglax.

297 Comparing and contrasting the results from the two classes of markers used here, can

298 provide important insights into the processes that have shaped the genetic makeup of this 299 species. The mtDNA control region network shows a distinctive star-like shape, which is 300 an indication of demographic expansion. Two approaches with different assumptions have been used to date such expansion, and both give the same time estimate: the roughhead 302 grenadier started expanding in the North Atlantic around 4,000 years ago. This corresponds roughly to 200 generations, which in evolutionary scale is considered recent.

304 This timing is consistent with new habitat becoming available after the Younger Dryas $305(\sim 11,700$ years ago). Unfortunately, based on the results, it is hard to speculate about the 306 possible location of the marine refugium which might have sourced the 307 recolonization/expansion into the North Atlantic Ocean (Kettle et al., 2011). It has been 308 hypothesised that the Atlantic Meridional Overturning Circulation (AMOC) went through 309 a strong spin-up after the last Younger Dryas glaciation and was responsible for one of the 310 most important dispersal events in the Atlantic, injecting larvae from the warmer southern area, into ocean currents that led to the fastest postglacial range expansion ever recorded in 312 the deep (Henry et al., 2014).

313 The comparison between diversity indices calculated from both sets of molecular markers (Table 1) allowed the determination of uneven contributions from the sampled populations to the measured genetic diversity. Overall, microsatellite markers show consistent 

homogeneity amongst locations. Mitochondrial DNA, on the other hand, shows that the

317 populations sampled at the western edge of the species distribution, Baffin Bay and Hatton

318 Bank, have the highest allelic richness and haplotypes diversity, contributing to the

319 majority of the total diversity. On the other hand, Svalbard registered the lowest values, for 320 any of the indices estimated from mtDNA (Table 2). Usually, lower genetic diversity, 321 hence lower adaptive capacity, is expected at population that originates from an expansion 322 (i.e. post-glacial) as they are subjected to a founder effect (Marko et al. 2010), compared to 323 those populations that still inhabits the refugial area (Diekmann and Serrao 2012).Yet, 324 supporting evidence is lacking (Zardi et al. 2015), so, once more, we cannot speculate on 325 the location of the refugium.

326 The $F_{\mathrm{ST}}$ analysis of microsatellites shows a low but statistically significant differentiation 327 of the Norwegian sample (Table 2). Having excluded the possibility of directional 328 selection acting upon these markers, we cannot conclude whether this is due to a spatial or 329 a temporal differentiation (these were the only fish caught in 2007). Nevertheless, 330 clustering analyses do not find Norway to be much different from the rest of the samples 331 (Fig. 2 Supplementary Material).

332 An interesting result unraveled by microsatellites is the presence of 15 half-sibs pairs 333 across the ocean. These are pairs of individuals born in different years that share at least 334 one parent. This could be explained by two possible causes: firstly, the roughhead 335 grenadier might have a unique spawning aggregation or secondly, and more likely, larval 336 and adult dispersal might play an important role in gene flow. Other members of the genus 337 Macrourus have been shown to have extended adult dispersal, and spawning migration has $338 \quad$ also been hypothesized for M. berglax (Garabana et al. 2016).Adult dispersal and 339 migration have been shown to play an important role in 'homogenizing' populations, even 
at oceanic scale (White et al. 2009), and could then explain the lack of genetic

341 differentiation detected in this study.

342 Lastly, the length distribution shows that the individuals caught in Baffin Bay are

343 significantly smaller than the ones coming from every other location (Fig. 4). This may

344 suggest that this area might be a breeding/nursery ground. Although this study can only

345 speculate about this, it would be important to consider this aspect in designing future

346 investigations, as this would be of vital importance for the management and conservation

347 of the species.

348 In conclusion, the roughhead grenadier Macrourus berglax shows no population structure

349 across the Atlantic Ocean. Whether this near-panmixia signal is due to a very large

350 population size or actual gene flow between locations is currently impossible to

351 disentangle. Nevertheless, caution should be taken when designing a management plan.

352 Previous studies using non-neutral markers did find significantly different units (Katsarou

353 and Naevdal, 2001), hence future work should aim at identifying markers under selection.

354 Local adaptation is now regarded as an important tool to discern populations in the marine 355 environment (Nielsen et al. 2012). Although this species is not a commercial target, it 356 makes up an important part of the bycatch, and more data should be gathered in order to 357 ensure its future conservation.

359 Conflict of interest: none

\section{Author contribution}

362 SM, RCa, HK and SS designed the study; IC analysed the data and wrote the manuscript 363 with input from SM and $\mathrm{RCa}$; $\mathrm{AMG}, \mathrm{CS}, \mathrm{SH}$ and $\mathrm{RCu}$ conducted lab work; all authors 364 commented on drafts of the manuscript. 


\section{Acknowledgements}

367 The authors would like to thank the members of all commercial and fishing expedition

368 through which samples for this study were collected.

369 This research has been funded as part of the DEECON project (EUROdeep, financially

370 supported by the European Science Foundation).

371 The author wish to thanks Francis Neat and Allan McDevitt for critical comments on the

372 manuscript draft, as well as the editor and two anonymous reviewers, whose work has

373 greatly improved the manuscript.

$376 \quad$ References

Antao, T., Lopes, A., Lopes, R.J., Beja-Pereira, A., Luikart, G., 2008. LOSITAN: a workbench to detect molecular adaptation based on a FST-outlier method. BMC Bioinf 9. doi:10.1186/1471-2105-9-323

Avise, J.C., 2000. Phylogeography: the history and formation of species. Harvard university press.

Baker, K.D., Devine, J.A., Haedrich, R.L., 2009. Deep-sea fishes in Canada’s Atlantic: Population declines and predicted recovery times. Environ. Biol. Fishes 85, 79-88. doi:10.1007/s10641-009-9465-8

Bandelt, H.J., Forster, P., Rohl, A., 1999. Median-joining networks for inferring intraspecific phylogenies. Mol. Biol. Evol. 16, 37-48.

Beaumont, M.A., Nichols, R.A., 1996. Evaluating loci for use in the genetic analysis of 
population structure. Proc. R. Soc. London B 263, 1619-1626.

Benjamini, Y., Hochberg, Y., 1995. Controlling the false discovery rate:/a practical and powerful approach to multiple testing. J R Stat Soc B 57, 289-300.

Bergner, L.M., Jamieson, I.G., Robertson, B.C., 2014. Combining genetic data to identify relatedness among founders in a genetically depauperate parrot, the Kakapo (Strigops habroptilus). Conserv. Genet. 15, 1013-1020. doi:10.1007/s10592-014-0595-y

Cano, J.M., Shikano, T., Kuparinen, A., Merila, J., 2008. Genetic differentiation, effective population size and gene flow in marine fishes: implications for stock management. J. Integr. F. Sci. 5, 1-10.

Carlsson, J., Shephard, S., Coughlan, J., N. Trueman, C., Rogan, E., Cross, T.F., 2011. Fine-scale population structure in a deep-sea teleost (orange roughy, Hoplostethus atlanticus). Deep-Sea Res Pt I 58, 627-636. doi:10.1016/j.dsr.2011.03.009.

Carvalho, G.R., Hauser, L., Martinshon, J., Naish, K., 2016. Fish, genes and genomes: contributions to ecology, evolution and management. J. Fish Bio. 89: 2471-2478.

Catarino, D., Stefanni, S., Menezes, G., 2013. Genetic diversity and length distribution of the Offshore Rockfish (Pontinus kuhlii) from three Atlantic archipelagos and seamounts. Deep-Sea Res Pt II 98: 160-169

Catarino, D., Knutsen, H., Veríssimo, A., Olsen, E.M., Jorde, P.E., Menezes, G., Sannæs, H., Company, J.B., Neat, F., Danovaro, R., Dell’Anno, A., Rochowski, B., Stefanni, S. 2015. The Pillars of Hercules as a bathymetric barrier to gene-flow promoting isolation in a global deep-sea shark (Centroscymnus coelolepis). Mol Ecol 24: 606179 
Chapuis, M.P., Estoup, A., 2007. Microsatellite null alleles and estimation of population differentiation. Mol. Biol. Evol. 24, 621-631.

Clarke, J., Millingan, R., Bailey, D., Neat, F., 2015. A scientific basis for regulating deepsea fishing by depth. Curr Biol 25: 2425-2429.

Cohen, D.M., 1990. Gadiform fishes of the world (order Gadiformes) : an annotated and illustrated catalogue of cods, hakes, grenadiers, and other gadiform fishes known to date. Food and Agriculture Organization of the United Nations.

Cunha, R.L., Coscia, I., Madeira, C., Mariani, S., Stefanni, S., Castilho, R., 2011. Ancient Divergence in the Trans-Oceanic Deep-Sea Shark Centroscymnus crepidater. PLoS One 7, e49196. doi:doi:10.1371/journal.pone.0049196

Dabney, A., Storey, J.D., Warnes, G.R., 2010. qvalue: Q-value estimation for false discovery rate control. R Package Version 1.24.20.

Devine, J. a., Watling, L., Cailliet, G., Drazen, J., Durán Muñoz, P., Orlov, a. M., Bezaury, J., 2012. Evaluation of potential sustainability of deep-sea fisheries for grenadiers (Macrouridae). J. Ichthyol. 52, 709-721. doi:10.1134/S0032945212100062

Diekmann, O. E., and E. A. Serrao. 2012. Range-edge genetic diversity: locally poor extant southern patches maintain a regionally diverse hotspot in the seagrass Zostera marina. Molecular Ecology 21: 1647-1657.

Drazen J.C. \& Haedrich R.L. (2012). A continuum of life histories in deep-sea demersal fishes. Deep-Sea Research I 61: 34-42. 
El Mousadik, A., Petit, R.J., 1996. High level of genetic differentiation for allelic richness among populations of the argan tree [Argania spinosa (L) Skeels] endemic to Morocco. Theor. Appl. Genet. 92, 832-839.

Excoffier, L., Lischer, H.E.L., 2010. Arlequin suite ver 3.5: A new series of programs to perform population genetics analyses under Linux and Windows. Mol. Ecol. Resour. $10,564-567$.

Falush, D., Stephens, M., Pritchard, J.K., 2003. Inference of population structure using multilocus genotype data: linked loci and correlated allele frequencies. Genetics 164, $1567-1587$.

Falush, D., Stephens, M., Pritchard, J.K., 2007. Inference of population structure using multilocus genotype data: dominant markers and null alleles. Mol. Ecol. Notes 7, $574-578$.

Fossen, I., Jørgensen, O.A., Gundersen, A.C., 2003. Roughhead grenadier (Macrourus berglax) in the waters off East Greenland: Distribution and biology. J. Northwest Atl. Fish. Sci. 31, 285-298.

Fu, Y.X., 1997. Statistical tests of neutrality of mutations against population growth, hitchhiking and background selection. Genetics 147, 915-925.

451 Gaither, M.R., Bowen, B.W., Rocha, L.A., Briggs, J.C., 2016. Fishes that rule the world: circumtropical distributions revisited. Fish Fish. 17, 664-679. 
roughhead grenadier (Macrourus berglax Lacepede 1801) reproductive biology including the evaluation of maturity ogive estimates. NAFO SCR Doc. 16.

457 Gonzales Costas, F., Murua, H. 2005. Assessment of roughhead grenadier, Macrourus berglax, in NAFO Subareas 2 and 3. NAFO SCR Doc. 05/54, Serial No. N5140.

Gonzales Costas, F., 2010. An assessment of NAFO roughhead grenadier Subarea 2 and 3 stock. NAFO SCR Doc. 10/32, Serial No. N5790.

Goudet, J., 1995. FSTAT (Version 1.2): A computer program to calculate F-statistics. J. Hered. 86, 485-486.

Gubili, C., Macleod, K., Perry, W., Hanel, P., Batzakas, I., Farrell, E.D., Lynghammar, A., Mancusi, C., Mariani, S., Menezes, G.M., Neat, F., Scarcella, G., Griffiths, A.M., 2016. Connectivity in the deep: Phylogeography of the velvet belly lanternshark, Deep Sea Research Part I: Oceanographic Research Papers.

Guindon, S., Gascuel, O., 2003. A simple, fast, and accurate algorithm to estimate large doi:10.1016/j.dsr.2016.07.002

Harpending, H.C., 1994. Signature of ancient population growth in a low-resolution mitochondrial DNA mismatch distribution. Human Biology 66: 561-600.

Harrison, H.B., Saenz-Agudelo, P., Planes, S., Jones, G.P., Berumen, M.L., 2013. Relative accuracy of three common methods of parentage analysis in natural populations. Mol Ecol 22: 1158-1170. clock of mitochondrial DNA. J. Mol. Evol. 22, 160-174. 
477 Hauser, L., Carvalho, G.R., 2008. Paradigm shifts in marine fisheries genetics: ugly hypotheses slain by beautiful facts. Fish Fish. 9, 333-362.

Helyar, S., Sacchi, C., Coughlan, J., Mariani, S., 2010. Novel microsatellite loci for a deep sea fish (Macrourus berglax) and their amplification in other grenadiers (Gadiformes: Macrouridae). Conserv. Genet. Resour. 2, 1-4.

Henry, L.-A., Frank, N., Hebbeln, D., Wienberg, C., Robinson, L., de Flierdt, T. van, Dahl, M., Douarin, M., Morrison, C.L., Correa, M.L., Rogers, A.D., Ruckelshausen, M., Roberts, J.M., 2014. Global ocean conveyor lowers extinction risk in the deep sea. Deep Sea Res. Part I Oceanogr. Res. Pap. 88, 8-16.

Hewitt, G.M., 2004. Genetic consequences of climatic oscillations in the Quaternary. Philos. Trans. R. Soc. London 359: 183-195.

ICES Advice, 2015. Roughhead grenadier (Macrourus berglax) in the North East Atlantic. Copenhagen.

Jombart, T., 2008. Adegenet: a R package for the multivariate analysis of genetic markers. Bioinformatics 24, 1403-1405.

Jombart, T., Devillard, S., Balloux, F., 2010. Discriminant analysis of principal component: a new method for the analysis of genetically structured populations. BMC Genet. 11, 94.

Jones, O.R., Wang, J., 2010. COLONY: a program for parentage and sibship inference from multilocus genotype data. Mol. Ecol. Resour. 10, 551-555.

Kalinowski ST, AP Wagner, ML Taper (2006). ML-Relate: a computer program for maximum likelihood estimation of relatedness and relationship. Mol. Ecol. Notes 
Katsarou E and Naevdal G (2001). Population genetic studies of the roughhead grenadier, Macrourus berglax L., in the North Atlantic Ocean. Fish. Res. 51, 207-215

Kettle, A.J., Morales-M Niz, A., Roselló-Izquierdo, E., Heinrich, D., Vøllestad, L.A., 2011. Refugia of marine fish in the northeast Atlantic during the last glacial maximum: concordant assessment from archaeozoology and palaeotemperature reconstructions. Clim. Past 7, 181-201.

Knutsen, H., Jorde, P.E., Bergstad, O.A., Skogen, M., 2012. Population genetic structure in a deepwater fish Coryphaenoides rupestris: Patterns and processes. Mar. Ecol. Prog. Ser. 460, 233-246.

Knutsen, H., Jorde, P.E., SannÆs, H., Rus Hoelzel, A., Bergstad, O.A., Stefanni, S., Johansen, T., Stenseth, N.C., 2009. Bathymetric barriers promoting genetic structure in the deepwater demersal fish tusk (Brosme brosme). Mol. Ecol. 18, 3151-3162.

Laptikhovsky, V. 2011. Migrations and structure of the species range in ridge-scaled rattail Macrourus carinatus (Southwest Atlantic) and their application to fisheries management. - ICES J. Mar. Sci., 68: 309-318.

Longmore, C., Trueman, C.N., Neat, F., Jorde, P.E., Knutsen, H., Stefanni, S., Catarino, D., Milton, J.A., Mariani, S., Gillanders, B., 2014. Ocean-scale connectivity and life cycle reconstruction in a deep-sea fish. Can. J. Fish. Aquat. Sci. 71, 1312-1323.

Lorance, P., Large, P. a, Bergstad, O.A., Gordon, J.D.M., 2008. Grenadiers of the Northeast Atlantic - Distribution, biology, fisheries, and their impacts, and developments in stock assessment and management. American Fisheries Society 
Lowe, W.H., Allendorf, F.W., 2010. What can genetics tell us about population connectivity? Mol. Ecol. 19: 3038-3051.

Magnússon, J.V., Magnússon, J., 1995. The distribution, relative abundance, and biology of the deep-sea fishes of the Icelandic slope and Reykjanes Ridge., in: Hopper, A.G. (Ed.), Deep-Water Fisheries of the North Atlantic Oceanic Slope. Kluwer Academic Publishers, Dordrecht, pp. 161-199.

Marko, P.B., J. M. Hoffman, S.A. Emme, T.M. McGovern, C.C. Keever, Cox, N.L., 2010. The 'Expansion-Contraction' model of Pleistocene biogeography: rocky shores suffer a sea change? Mol. Ecol. 19: 146-169.

Miller, S.A., Dykes, D.D., Polesky, H.F., 1988. A simple salting out procedure for extracting DNA from human nucleated cells. Nuc. Ac. Res. 16.

Morato, T., Watson, R., Pitcher, T.J., Pauly, D., 2006. Fishing down the deep. Fish Fish. 7, 24-34.

Münster, J., Kochmann, J., Klimpel, S., Klapper, R., \& Kuhn, T. (2016). Parasite fauna of Antarctic Macrourus whitsoni (Gadiformes: Macrouridae) in comparison with closely related macrourids. Parasites \& Vectors 9: 403.

Murua, H., 2003. Population structure, growth and reproduction of roughhead grenadier on the Flemish Cap and Flemish Pass. J. Fish Biol. 63, 356-373.

O’Sullivan, M., Verspoor, E., Wright, P.J., 2003. The potential for using molecular techniques to determine population structure in marine finfish species of interest to the Scottish industry. Fisheries Research Services Internal Report No 19/03. 
544 Ostellari, L., Bargelloni, L., Penzo, E., Patarnello, P., Patarnello, T., 1996. Optimization of 545 single-strand conformation polymorphism and sequence analysis of the mitochondrial 546 control region in Pagellus bogaraveo (Sparidae, Teleostei): rationalized tools in fish 547 population biology. Anim. Genet. 27, 423-427

548 Palumbi, S., Romano, S., Mcmillan, W.O., Grabowski, G., 1991. The Simple Fool’ S $549 \quad$ Guide To PCR. October 96822, 1-45.

550 Patarnello, T., Volckaert, F., Castilho, R., 2007. Pillars of Hercules: is the AtlanticMediterranean transition a phylogeographical break? Mol. Ecol. 16, 4426-4444.

552 Peakall, R., Smouse, P.E., 2006. GENALEX 6: genetic analysis in Excel. Population genetic software for teaching and research. Mol. Ecol. Notes 6, 288-295.

Petit, R.J., Pons, O., 1998. Bootstrap variance of diversity and differentiation estimators in

Posada, D., 2008. jModelTest: Phylogenetic Model Averaging. Mol. Biol. Evol. 25, 12531256.

Pritchard, J.K., Stephens, M., Donnelly, P., 2000. Inference of population structure using multilocus genotype data. Genetics 155, 945-959.

560 R Core Team, 2016. R: A Language and Environment for Statistical Computing.

561 Reiss, H., Hoarau, G., Dickey-Collas, M., Wolff, W.J., 2009. Genetic population structure of marine fish: mismatch between biological and fisheries management units. Fish and Fish., 10, 361-395. Evol. 17: 242-245. 
566 Rogers, A.R., Harpending, H.C., 1992. Population growth makes waves in the distribution 567 of pairwise nucleotide differences. Am. J. Phys. Anthropol. 140, 552-569.

568 Savvatimsky, P.I., 1989. Investigations of roughhead grenadier (Macrourus berglax L) in

Schenekar, T., Weiss, S., 2011. High rate of calculation errors in mismatch distribution

Waples, R.S., Do, C., 2008. LDNE: a program for estimating effective population size from data on linkage disequilibrium. Mol. Ecol. Resour. 8, 753-756 changes in depth of fishing. Fish. Res. 140, 63-65. 
600

601

602

603

604

605

606

607

608

609

White, T.A., Stefanni, S., Stamford, J., Hoelzel, A.R., 2009. Unexpected panmixia in a long-lived, deep-sea fish with well-defined spawning habitat and relatively low fecundity. Mol. Ecol. 18, 2563-2573.

Zardi, G.I., Nicastro, K.R., Serrão E.A., Jacinto, R., Monteiro, C.A., and Pearson, G.A., 2015. Closer to the rear edge: ecology and genetic diversity down the core-edge gradient of a marine macroalga. Ecosphere 6(2):23.

(1)

5

\section{6}

7

\section{8}

9

\section{0}

03 
610

611

612

613

614

615

616

617

618

619

620

621

Table 1 Sampling locations, population codes (ID), year of sampling (Year) and genetic diversity parameters inferred from mitochondrial DNA and microsatellites. $N$, number of individuals screened; $N_{H}$, number of haplotypes; $h$, haplotype diversity; $\pi$, nucleotide diversity; $A_{r}$, allelic richness; $N_{A}$, number of alleles; $H_{o}$, observed heterozygosity; $H_{E}$, expected heterozygosity; $F_{I S}$, inbreeding coefficient (in bold, values that are significant; $\mathrm{p}<0.05)$.

\begin{tabular}{|c|c|c|c|c|c|c|c|c|c|c|c|c|c|}
\hline \multirow{2}{*}{ Location } & \multirow{2}{*}{ ID } & \multirow{2}{*}{ Year } & \multicolumn{5}{|c|}{ Mitochondrial DNA } & \multicolumn{6}{|c|}{ Microsatellites } \\
\hline & & & $\mathrm{N}$ & $\mathrm{N}_{\mathrm{H}}$ & $\mathrm{h}$ & $\pi$ & $A \mathrm{r}$ & $\mathrm{N}$ & $\mathrm{N}_{\mathrm{A}}$ & $A \mathrm{r}$ & $H_{\mathrm{O}}$ & $H_{\mathrm{E}}$ & $F_{\text {IS }}$ \\
\hline East Greenland & EGree & 2000 & 12 & 5 & 0.58 & 0.0014 & 2.73 & 95 & 9.86 & 5.14 & 0.668 & 0.665 & -0.005 \\
\hline South Greenland & SGree & 2003 & 25 & 6 & 0.30 & 0.0006 & 1.92 & 88 & 9.57 & 4.88 & 0.673 & 0.650 & -0.020 \\
\hline George Bank & GEO & 2004 & 12 & 3 & 0.32 & 0.0004 & 1.67 & 52 & 7.86 & 4.96 & 0.599 & 0.649 & 0.070 \\
\hline Svalbard & SVA & 2002 & 20 & 3 & 0.19 & 0.0002 & 1.00 & 80 & 8.26 & 5.02 & 0.535 & 0.668 & 0.200 \\
\hline Hatton Bank & HAT & 2000 & 14 & 7 & 0.76 & 0.0015 & 4.51 & 50 & 7.71 & 4.82 & 0.592 & 0.619 & 0.040 \\
\hline Flemish Cap & FLE & 2002 & 11 & 7 & 0.82 & 0.0018 & 3.08 & 21 & 5.43 & 4.89 & 0.530 & 0.674 & 0.210 \\
\hline Baffin Sea & $\mathrm{BAF}$ & 2001 & 17 & 10 & 0.79 & 0.0017 & 5.56 & 75 & 9.14 & 4.77 & 0.637 & 0.646 & 0.010 \\
\hline Norway & NOR & 2007 & 13 & 5 & 0.54 & 0.0009 & 3.07 & 98 & 7.29 & 4.64 & 0.623 & 0.629 & 0.010 \\
\hline
\end{tabular}

Table 2 Population pairwise comparisons: microsatellite-derived FST in the lower diagonal, and mtDNA-based $\Phi S T$ in the upper section. In bold, values that remain significant $(\mathrm{p}<0.05)$, and in bold and italic those that remain significant after Bonferroni's correction.

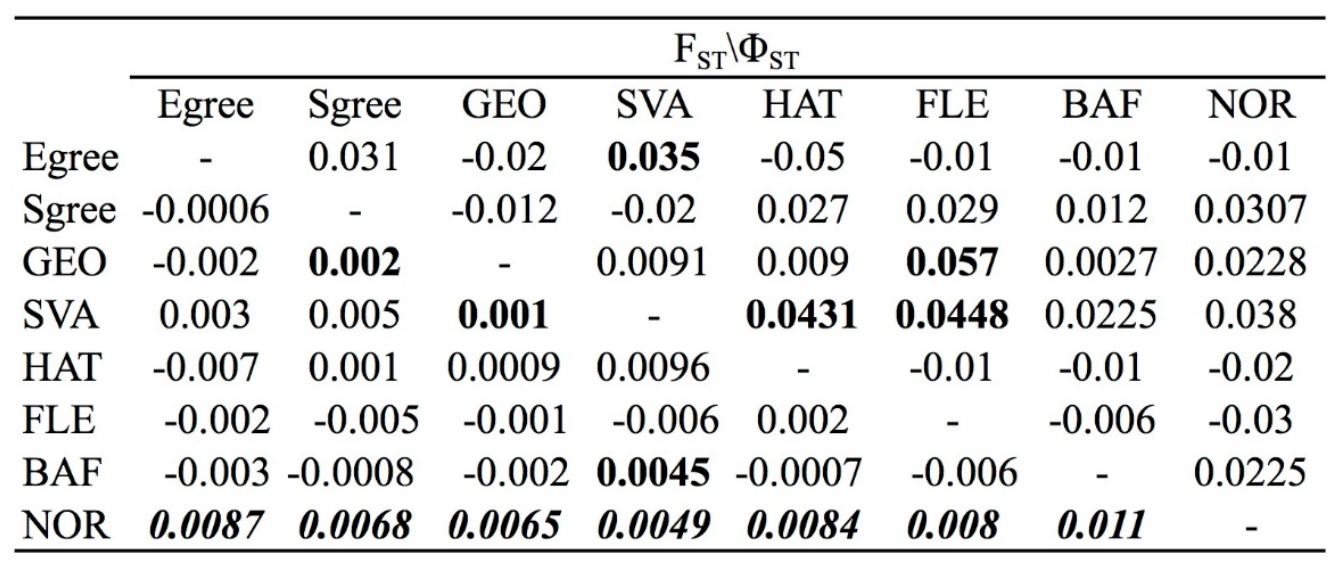




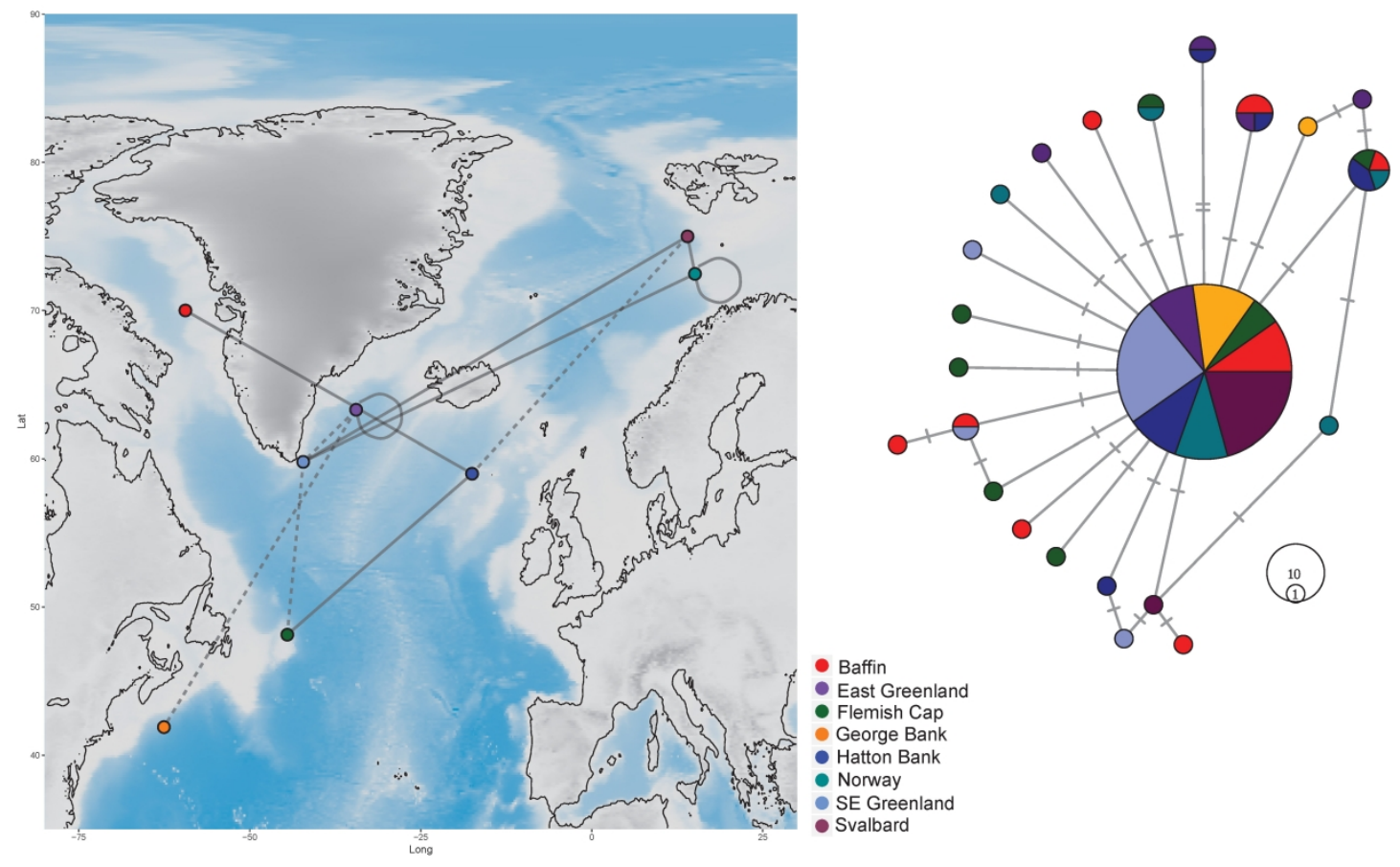

627 Figure 1 Map showing the colour-coded sampling locations. The lines connecting the 628 locations represent the half-sib pairs: dashed lines for two pairs between locations, whereas 629 all the other lines represent one pair (see also Table 1 supplementary material). On the right, 630 the median-joining network of mitochondrial haplotypes. 


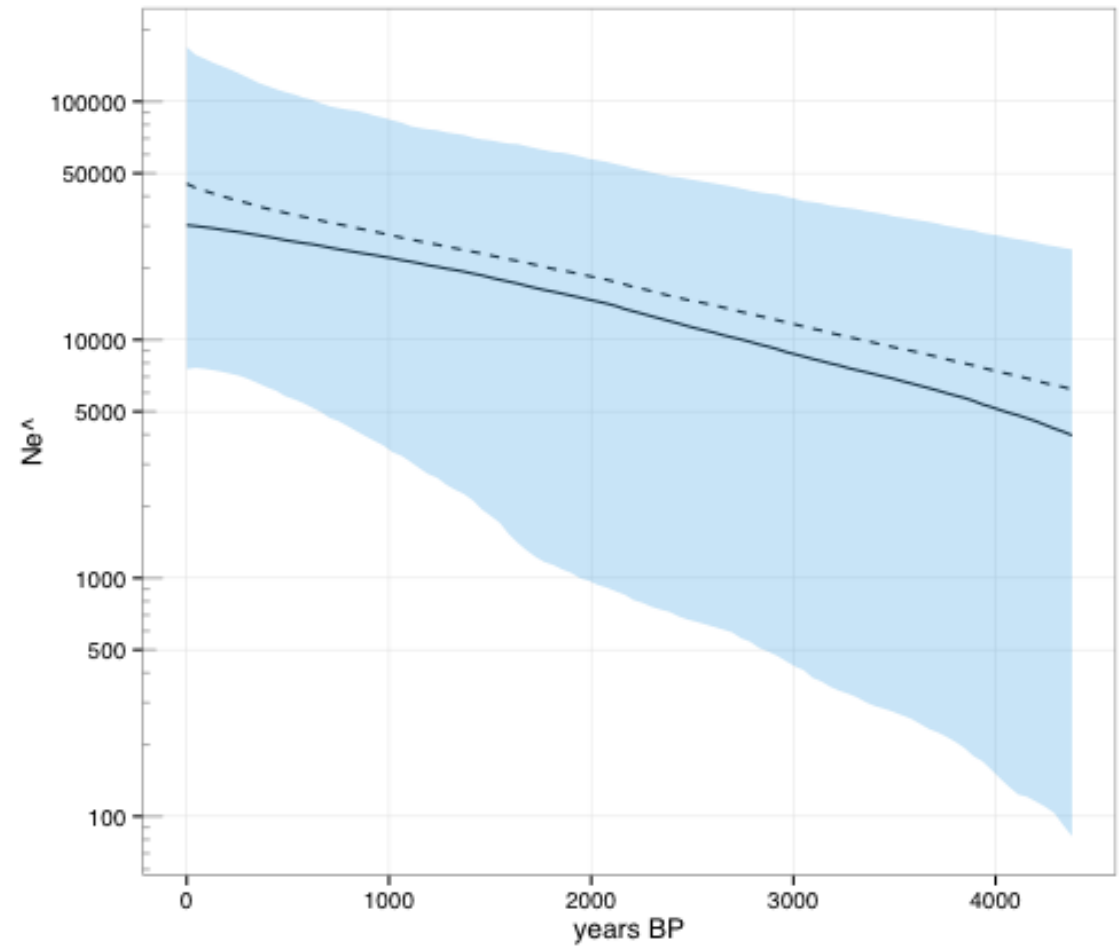

634 Figure 2 Bayesian Skyline plot, showing the historical trend of female effective

635 population size. The continuous and dashed lines represent the median and mean values, 636 respectively. The shaded area represents the 95\% Confidence interval.

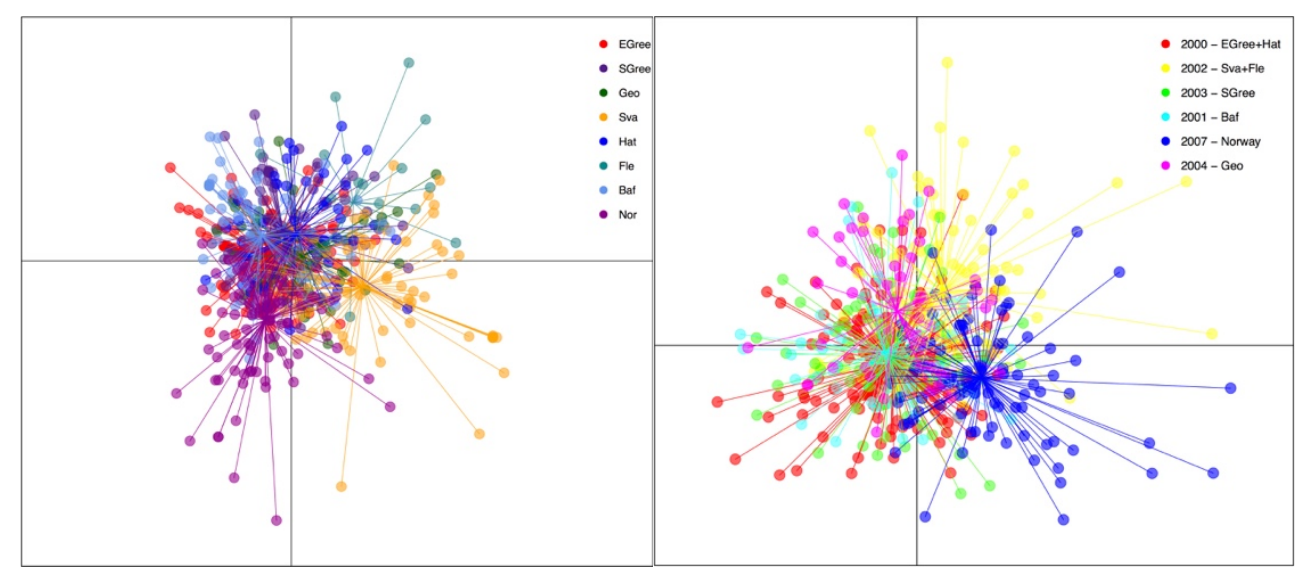

642 Figure 3 DAPC scatter plots by sampling locations (left) and year of capture (right). In the 643 latter, the corresponding locations per year of capture are indicated in the legend. 

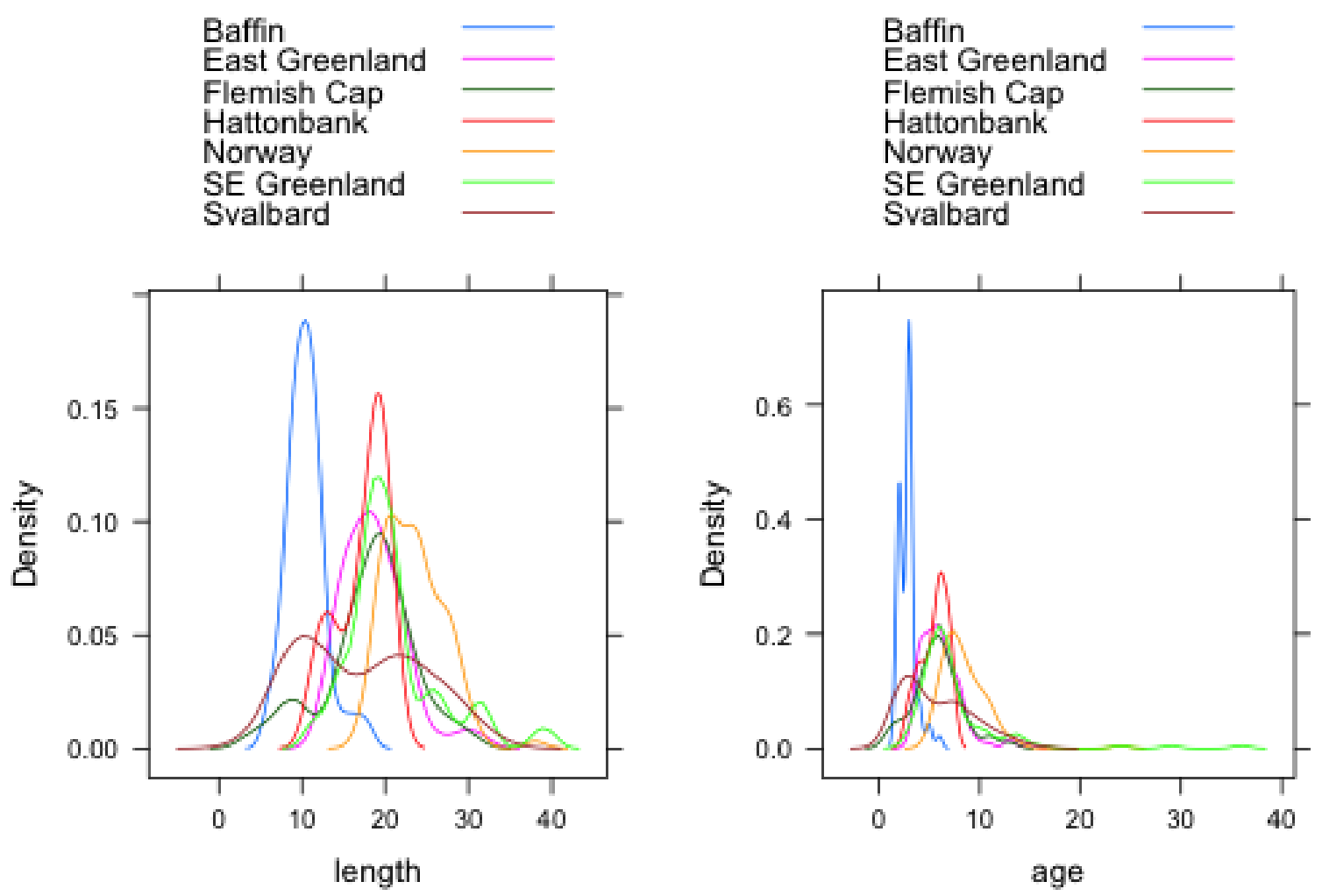

651 Figure 4 Length frequency distributions by location.

652 
661 Supplementary Material
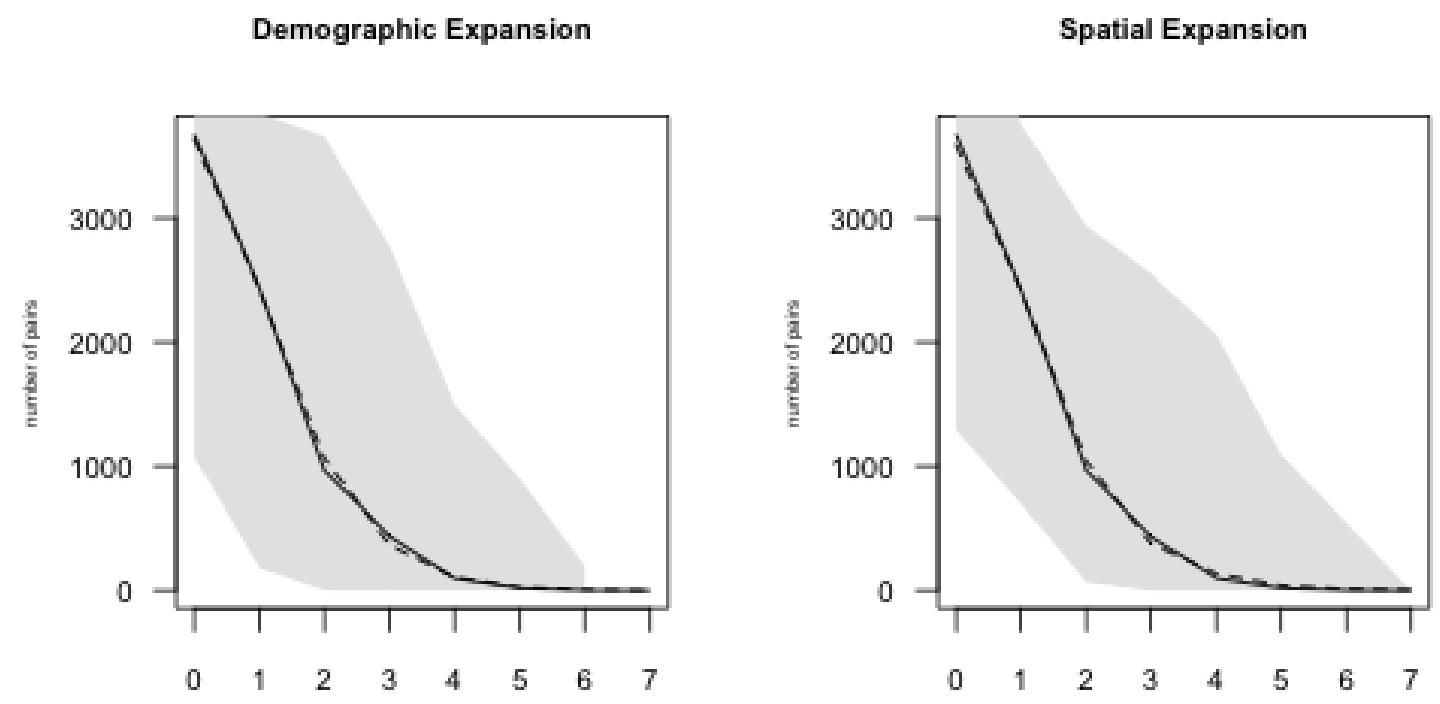

662

663

Parwas Deflerenses

Parwas Deflerences

Figure 1 Supplementary Material: Mismatch distributions. The shaded grey area

664 represents the $95 \%$ confidence interval. 

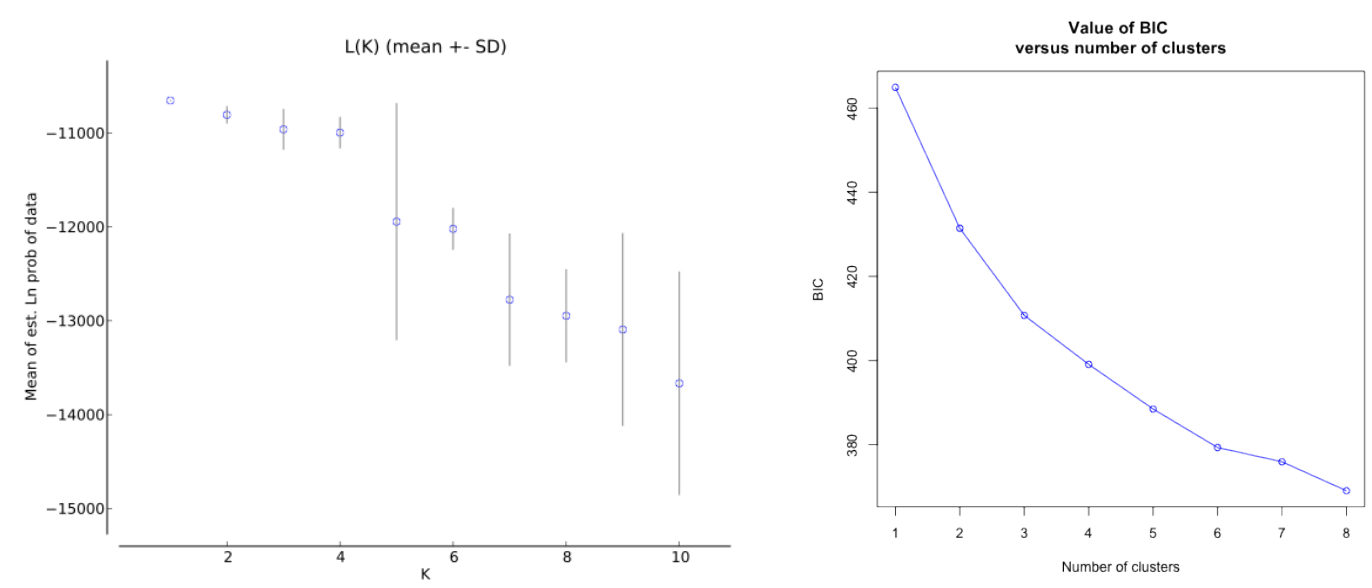

671

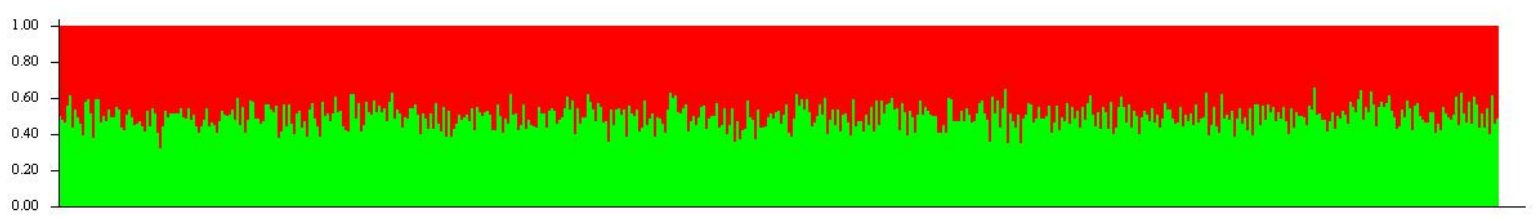

672 Figure 2 Supplementary Material: Topleft - Mean Likelihood inferred from 673 STRUCTURE; topright - graphical inference of the number of genetic clusters from DAPC.

674 Both graphs show a trend that is interpreted with the absence of genetic clusters 675 (homogeneity). This is particularly evident in the barplot at the bottom (inferred from 676 STRUCTURE): on the Y-axis the Q-value, and index of admixture; on the X-axis the 677 individuals. 
Figure 3 Supplementary Material: Boxplot representing the anal fin length measured at
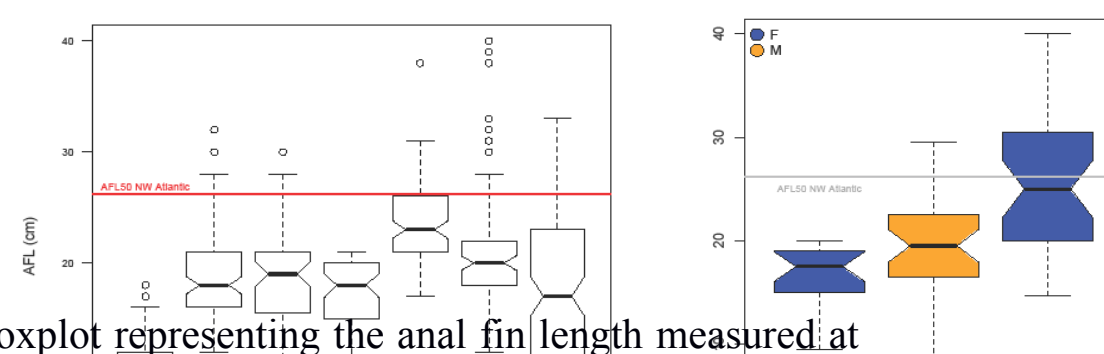
seven locations. Left: The red line represents the length ${ }_{\circ}^{\circ}$ at first maturity for $M$. berglax in the Atlantic. The notch in each box represents the $95 \%$ confidence plotted by sex for two locations

Table 1 Supplementary Material. Half-sibs pairs detected and relative likelihood inferred

696 from COLONY. Sibship analyses results: the combination of columns Off1 and Off2 697 indicate the pair of individuals for which a significant relationship has been found. The third column (Colony) contains the probabilities for such relationship. Colony has found only half-sibs in the datasets. The fourth column (ML-Relate) reports the findings of the ML- 
700 Relate software. The latter confirms the half-sibs relationships. The only discrepancy is for 701 the pair Nor10-Nor48, which ML-Relate identify as Parent-Offspring pair.

$\begin{array}{llll}\text { Off1 } & \text { Off2 } & \text { Colony } & \text { ML-Relate } \\ \text { SGre5 } & \text { Fle4 } & 0.894 & \text { Half-Sib } \\ \text { Sva17 } & \text { Hat28 } & 0.884 & \text { Half-Sib } \\ \text { Hat27 } & \text { Baf61 } & 0.872 & \text { Half-Sib } \\ \text { EGre73 } & \text { Geo49 } & 0.868 & \text { Half-Sib } \\ \text { Sva10 } & \text { Nor8 } & 0.845 & \text { Half-Sib } \\ \text { EGre40 } & \text { Geo46 } & 0.840 & \text { Half-Sib } \\ \text { Sva25 } & \text { Hat15 } & 0.839 & \text { Half-Sib } \\ \text { SGre78 } & \text { Sva57 } & 0.832 & \text { Half-Sib } \\ \text { EGre26 } & \text { EGre40 } & 0.829 & \text { Half-Sib } \\ \text { SGre74 } & \text { Nor6 } & 0.823 & \text { Half-Sib } \\ \text { EGre53 } & \text { SGre54 } & 0.813 & \text { Half-Sib } \\ \text { Hat24 } & \text { Fle9 } & 0.810 & \text { Half-Sib } \\ \text { SGre39 } & \text { Fle4 } & 0.807 & \text { Half-Sib } \\ \text { Nor10 } & \text { Nor48 } & 0.807 & \text { Parent-Offspring } \\ \text { EGre63 } & \text { SGre60 } & 0.800 & \text { Half-Sib }\end{array}$

